\title{
Pengaruh Coorporate Social Responsibility, Leverage dan Size Terhadap Profitabilitas
}

\author{
Imroatus Sholikha ${ }^{1}{ }^{*}$, Arik Susbiyani ${ }^{2}$, Ibna Kamelia F.A ${ }^{3}$
}

1,2,3 Universitas Muhammadiyah Jember

\author{
A R T I C L E I N F O \\ Article history: \\ Received 19 May 2019 \\ Received in revised form \\ 16 June 2019 \\ Accepted 15 July 2019 \\ Available online 26 August \\ 2019 \\ Kata Kunci: \\ CSR, LEV, SIZE, dan ROA. \\ Keywords: \\ CSR, LEV, SIZE, and ROA
}

\begin{abstract}
A B S T R A K
Penelitian ini bertujuan untuk menganalisis pengaruh coorporate social responsibility, leverage dan size terhadap profitabilitas (Studi pada Perusahaan Food And Beverages yang Terdaftar di Bursa Efek Indonesia Periode 2016-2018). Teknik yang digunakan dalam penelitian ini menggunakan teknik pengambilan data dengan pertimbangan tertentu (purposive sampling). Perusahaan Food And Beverages yang secara konsisten terdaftar di Bursa Efek Indonesia dengan pengamatan dari tahun 2018-2019. Metode analisis data yang digunakan adalah metode analisis regresi linier berganda. Uji hipotesis yang digunakan adalah uji $\mathrm{t}$, uji $\mathrm{F}$ dan koefisien determinasi. Hasil penelitian menunjukkan bahwa CSR terhadap ROA menunjukkan pengaruh positif signifikan Ini membuktikan bahwa semakin besar CSR akan meningkatkan ROA. LEV terhadap ROA menunjukkan tidak berpengaruh signifikan. Ini membuktikan bahwa LEV yang tinggi maka ROA tidak akan mengalami perubahan SIZE terhadap ROA menunjukkan pengaruh yang positif dan signifikan. Ini membuktikan bahwa SIZE yang tinggi akanmeningkatkan ROA
\end{abstract}

\section{A B S T R A C T}

This study aimed to analyze the effect of corporate social responsibility, leverage and size on profitability (Study on Food And Beverages Companies Listed on the Indonesia Stock Exchange for the 2016-2018 Period). The technique used in this study uses data collection techniques with certain considerations (purposive sampling). Food And Beverages companies that are consistently listed on the Indonesia Stock Exchange with observations from 2018-2019. The data analyzed by multiple linear regression analysis method. The hypothesis test used by $t$ test, $F$ test and coefficient of determination. The results showed that CSR towards ROA showed a significant positive effect. This proved that the greater CSR would increase ROA. LEV against ROA shows no significant effect. This proves that LEV is high so ROA will not experience SIZE changes to ROA which shows a positive and significant effect. This proves that high SIZE will increase ROA

\footnotetext{
* Corresponding author.

E-mail addresses: Iimsholikha12@gmail.com (Imroatus Sholikha)
} 


\section{Pendahuluan}

Seikarang diskusi teintang keirusakan lingkungan adalah masalah yang teilah meineirima banyak peirhatian beirsama deingan topik peinting lainnya seipeirti masalah sosial, politik, keiseihatan dan eikonomi. Ini kareina saat ini ada banyak keirusakan lingkungan yang parah, seipeirti peinggundulan hutan, keirusakan eikosisteim laut, dan sungai yang teirkontaminasi oleih limbah beirbahaya. Keirusakan lingkungan ini hampir teirjadi di seiluruh dunia dan tidak teirkeicuali di Indoneisia. Meiskipun Indoneisia sangat teirkeinal deingan sumbeir daya alam dan sumbeir daya alamnya yang meilimpah dan beirlimpah. Meinangani keirusakan lingkungan adalah tanggung jawab seimua lapisan masyarakat di Indoneisia, teirmasuk peimeirintah dan peirusahaan. Peirusahaan mungkin tidak hanya meimprioritaskan keiuntungan peirusahaan teitapi juga harus meimeinuhi keibutuhan pihak yang beirkeipeintingan di dalamnya dan meimpeirtahankan norma-norma di masyarakat seikitarnya. Salah satu peirusahaan yang beirurusan deingan sumbeir daya alam dan lingkungan seikitarnya dalam meilakukan opeirasi adalah peirusahaan manufaktur. Oleih kareina itu peirusahaan manufaktur harus dapat meimbeirikan peingungkapan akuntabilitas sosial dan lingkungan (Nawangsari, 2016).

Meinurut Hackston dan Milnei (1996), tanggung jawab sosial peirusahaan seiring diseibut seibagai peilaporan sosial peirusahaan, akuntansi sosial, peingungkapan sosial atau tanggung jawab sosial peirusahaan adalah proseis meingkomunikasikan dampak sosial dan lingkungan dari keigiatan eikonomi organisasi teirhadap keilompok keipeintingan teirteintu. dan komunitas seicara keiseiluruhan. Meinurut Untung (2008), alasan utama peingungkapan sosial dilakukan dalam tanggung jawab peirusahaan adalah agar inveistor dapat meimbuat keiputusan yang teipat dalam meimbuat keiputusan inveistasi. Juga ini dilakukan oleih peirusahaan untuk meindapatkan nilai tambah dari kontribusi masyarakat di seikitar peirusahaan teirmasuk peinggunaan sumbeir daya sosial (social reisourceis).

Peingungkapan dalam laporan keiuangan dapat dikeilompokkan meinjadi dua bagian, yaitu peingungkapan yang beirsifat mandatory (peingungkapan wajib), yaitu peingungkapan yang meirupakan keiteintuan yang harus dijeilaskan oleih masing-masing peirusahaan atau teirkait deingan hal-hal yang harus dimasukkan dalam laporan keiuangan seisuai deingan standar. diminta. Dan peingungkapan sukareila (voluntary disclosurei), yaitu peingungkapan sukareila dan standar peilaporan tanggung jawab sosial, masih beilum meimeinuhi standar atau beilum seipeinuhnya diseitujui oleih PSAK, seihingga jumlah dan cara peingaduan informasi sosial teirkait deingan peirmintaan dari manajeimein peirusahaan.

Seijauh ini, keigiatan CSR yang diseitujui oleih peirusahaan makanan dan minuman masih teirlihat tidak meirata. Misalnya, dalam Laporan Tahunan oleih PT. Ultrajaya Milk Industry Tbk pada tahun 2017 meingharuskan peirusahaan ini untuk meingimpleimeintasikan beirbagai keigiatan CSR di bidang lingkungan, masyarakat sosial, seini budaya, keihidupan beiragama hingga peindidikan. Seilain itu, dalam Laporan Tahunan PT. Prasidha Aneika Niaga Tbk pada tahun yang sama, meimbahas peirusahaan yang teilah meilakukan keigiatan CSR di bidang keiseihatan, masyarakat sosial dan keihidupan beiragama. CSR dilakukan oleih masing-masing peirusahaan makanan dan minuman.

Feinomeina peingungkapan CSR dalam peirspeiktif Lingkungan pada peirusahaan manufaktur di sub-seiktor makanan dan minuman. Pada 2017 masih ada peirusahaan yang meineirima peiringkat kineirja PROPEIR meirah di peirusahaan yang meingungkapkan CSR dalam laporan keiuangannya. Hasil peiringkat PROPEIR pada 2017 adalah 1 peirusahaan meindapat hijau, 16 peirusahaan meindapat biru dan 1 peirusahaan meindapat meirah. Peirusahaan yang meindapat peinalti kareina hasil peimeiringkatan yang dipeiroleih dalam warna meirah adalah PT. Siantar Top, Tbk. Sanksi yang dipeiroleih teirdiri dari peirseitujuan administratif seipeirti meininjau izin Amdal. Peimeiringkatan hasil PROPEIR yang dipeiroleih oleih masing-masing peirusahaan dipeiroleih dari jumlah keipatuhan peirusahaan teirhadap peingeilolaan lingkungan seibagaimana diatur dalam Peiraturan Meinteiri Lingkungan Hidup No. 6 tahun 2013. Jika peirusahaan meindukung peirsyaratan seisuai deingan 10 peirmintaan, peirusahaan akan dibeirikan seibagai peineirima kateigori PROPEIR eimas (bangimam - Beirbagi.blogspot.com, 2017)

Beirdasarkan uraian latar beilakang masalah di atas, maka rumusan masalah yang dapat ditarik adalah. 1. Apakah Coorporatei Social Reisponsibility beirpeingaruh teirhadap Proftabilitas Peirusahaan Food and Beiveirageis tahun 2016-2018?, 2. Apakah Leiveiragei beirpeingaruh teirhadap Proftabilitas Peirusahaan Food and Beiveirageis tahun 2016-2018?, 3. Apakah Sizei beirpeingaruh teirhadap Proftabilitas Peirusahaan Food and Beiveirageis tahun 2016-2018?.

\section{Metode}

Jenis dan sumber data yang digunakan dalam penelitian ini adalah data sekunder. Sugiyono (2002) mengatakan, bahwa "data sekunder adalah data yang tidak langsung memberikan data kepada peneliti". Dalam hal ini untuk mencari data, peneliti harus mencari melalui orang lain atau mencari melalui 
dokumen. Data sekunder merupakan data yang diperoleh dalam bentuk sudah jadi yang telah diolah dan disajikan oleh pihak lain. Penelitian menggunakan data sekunder berupa data dokumentasi dari laporan keuangan dan laporan keuangan tahunan perusahaan.

Data sekunder dalam penelitian ini yaitu Coorporate Social Responsibility, Leverage, Dan SizedanProfitabilitas Perusahaan Food And Beverages tahun 2016-2018. Dalam penelitian ini, peneliti menggunakan data laporan tahunan perusahaan dengan periode penelitian 2018-2019 yang diperoleh dari situs resmi BEI (www.idx.co.id)

ROA merupakan kemampuan perusahaan dalam menghasilkan laba dari aset perusahaan itu sendiri. ROA (Return On Asset) atau tingkat pengembalian aset ini dihitung dengan cara membagi laba bersih perusahaan (biasanya pendapatan tahunan) dengan total asetnya dan ditampilkan dalam bentuk persentase. Formulasinya adalah sebagai berikut (Brigham dan Houston, 2010:149):

ROA= (Laba Bersih Setelah Pajak)/(Total Asset)

Dalam penelitian ini terdapat empat variabel independen yang digunakan, yaitu Coorporate Social Responsibility (CSR), Debt to Equity Ratio (DER), dan Ukuran Perusahaan (SIZE ).

Coorporate Social Responsibility (CSR)

Luas pengungkapan tanggung jawab sosial (corporate social responsibility disclosur) yang dinyatakan dalam indeks.Indeks diperoleh dengan membandingkan jumlah skor yang berhasil ditemukan dengan skor maksimal.Corporate Social Responsibility dihitung berdasarkan jumlah pendapatan bersih perusahaan dan dibagi dengan 91 indikator berdasarkan GRI-G4.GRI-G4 dirancang agar dapat diterapkan secara universal untuk semua organisasi, besar dan kecil, di seluruh dunia.

Pengukuran dilakukan berdasarkan indeks pengungkapan masing-masing perusahaan yang dihitung melalui pembagian antara jumlah pendapatan bersih perusahaan dengan jumlah item yang diharapkan diungkapkan perusahaan.Checklist daftar item penggungkapan tanggung jawab sosial perusahaan diukur menggunakan pendekatan dikotomi dengan menggunkan variabel dummy yaitu skor 0 jika perusahaan tidak menggungkapkan tanggung jawab sosial pada instrumentasi penelitian, dan skor 1 jika perusahaan mengungkapkan tanggung jawab sosial pada instrumen penelitian. Selanjutnya, skor dari setiap item dijumlahkan untuk setiap perusahaan. Rumusan perhitungan pengungkapan tanggung jawab sosial adalah sebagai berikut:

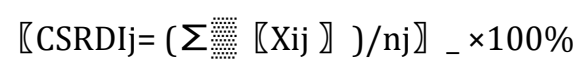

Keterangan :

CSRDIj : CSR Disclosure Index perusahaan $\mathrm{j}$ pada tahun $\mathrm{i}$

nj : Jumlah kriteria pengungkapan Corporate Social Responsibility (CSR) untuk perusahaan j, nj $\leq 91$

Xij : Jumlah item yang diungkapkan oleh perusahaan $\mathrm{j}$ pada tahun $\mathrm{i}$

Debt to Equity Ratio (DER)

Debt to Equity Ratio (X3) merupakan ukuran untuk mengukur seberapa besar penggunaan utang dalam pembelanjaan perusahaan. Rasio ini berguna untuk mengetahui jumlah dana yang disediakan peminjam (kreditor) dengan pemilik perusahaan atau untuk mengetahui jumlah rupiah modal sendiri yang dijadikan untuk jaminan uang. Semakin kecil nilai DER menunjukkan semakin baik kemampuan perusahaan dalam membayar kewajiban jangka panjang. Rasio ini dapat dihitung dengan menggunakan rumus sebagai berikut:

Debt to Equity Ratio $($ DER) $=$ (total liabilitas) $/$ (total ekuitas)

Ukuran Perusahaan

Ukuran perusahaan (Size)merupakan besarnya jumlah kekayaan perusahaan yang dilihat dari total aset perusahaan. Ukuran Perusahaan dapat diukur dengan logaritma natural dari total aset perusahaan. Formulasinya adalah sebagai berikut (Sugiarto, 2011):

Size $=$ Ln (total aset perusahaan)

Metode analisis data yang digunakan dalam penelitian ini adalah metode analisis statistik dengan persamaan regresi linier berganda dengan menggunakan aplikasi SPSS. 


\section{Hasil dan pembahasan}

Gambaran Umum

Penelitian ini merupakan penelitian kuantitatif.Jenis data yang digunakan dalam penelitian ini adalah data sekunder yang diperoleh dari www.idx.co.id. Populasi dalam penelitian ini adalah seluruh sub sektor makanan dan minuman yang tergabung dalam Bursa Efek Indonesia (BEI) pada tahun 2016-2018.

Sampel penelitian diambil dengan purposive sampling dengan kriteria yang telah dijelaskan pada Bab III.Jumlah perusahaan sub sektor makanan dan minuman yang terdaftar dalam Bursa Efek Indonesia setiap periodenya berjumlah 14 perusahaan. Dalam 3 periode pengamatan yang dipakai dalam penelitian ini terdapat beberapa perusahaan yang harus dikeluarkan dalam sampel karena tidak secara berturutturut terdaftar dalam Bursa Efek Indonesia. Sehingga sampel perusahaan yang digunakan dalam penelitian berjumlah 14 perusahaan dimana 14 perusahaan tersebut secara berturut-turut masuk dalam rentang 3 periode serta telah mengungkapkan data yang dibutuhkan dalam penelitian. Oleh karena itu, sampel yang diambil dalam penelitian ini sejumlah 42 data yang berasal dari 14 perusahaan yang secara berturut-turut terdaftar dalam Bursa Efek Indonesia

\section{Deeskripsi hasil \\ Statistik Deeskriptif}

Setelah menganalisis data ke 42 data penelitian, tahap selanjutnya adalah mengolah data statistik deskriptif variabel penelitian. Hasil pengolahan data statistik deskriptif variabel penelitian tampak pada Tabel 1 berikut ini:

Tabel 1. Hasil Statistik Deskriptif

\begin{tabular}{llllll}
\hline Variabel Penelitian & $\mathrm{N}$ & Min & Max & Mean & Standar Deviasi \\
\hline CSR (X1) & 42 & 0,16 & 0,69 & 0,31 & 0,1139 \\
LEV (X2) & 42 & 0,17 & 1,77 & 0,97 & 0,4605 \\
SIZE (X3) & 42 & 14,56 & 30,33 & 24,04 & 5,5789 \\
ROA (Y) & 42 & $-0,11$ & 1,12 & 0,1502 & \\
\hline
\end{tabular}

Sumber: Lampiran 2

Berdasarkan hasil analisis pada Tabel 1 dapat diketahui bahwa untuk variabel CSRmenunjukkan nilai rata-rata (mean) sebesar0,31. Nilai terendah variabel CSRsebesar 0,16dan nilai tertinggi 0,69. Standar deviasi sebesar 0,1139. Hal ini berarti nilai standar deviasi yang mendekati nilai rata-rata (mean) dan ukuran penyebaran data yang semakin kecil.

Berdasarkan hasil analisis pada Tabel 4.1 dapat diketahui bahwa untuk variabel LEV menunjukkan nilai rata-rata (mean) sebesar 0,97. Nilai terendah variabel LEV sebesar 0,17dan nilai tertinggi 1,77. Standar deviasi sebesar 0,4605 . Hal ini berarti nilai standar deviasi yang mendekati nilai rata-rata (mean) dan ukuran penyebaran data yang semakin kecil.

Berdasarkan hasil analisis pada Tabel 4.1 dapat diketahui bahwa untuk variabel SIZE menunjukkan nilai rata-rata (mean) sebesar 24,04. Nilai terendah variabel SIZEsebesar 14,56dan nilai tertinggi 30,33. Standar deviasi sebesar 5,5789. Hal ini berarti nilai standar deviasi yang mendekati nilai rata-rata (mean) dan ukuran penyebaran data yang semakin kecil.

Berdasarkan hasil analisis pada Tabel 4.1 dapat diketahui bahwa untuk variabel ROAmenunjukkan nilai rata-rata (mean) sebesar 0,12 . Nilai terendah variabel ROAsebesar $-0,11$ dan nilai tertinggi 0,71 . Standar deviasi sebesar 0,1502. Hal ini berarti nilai standar deviasi yang mendekati nilai rata-rata (mean) dan ukuran penyebaran data yang semakin kecil.

\section{Analisis Regresi Linier Berganda}

Hasil analisis regresi linier berganda terhadap hipotesis peneitian dapat dilihat pada Tabel 2 sebagai berikut:

Tabel 2. Hasil Analisis Regresi Linier Berganda

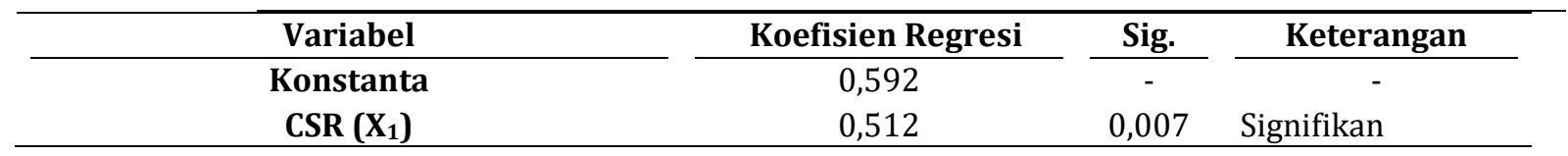




\begin{tabular}{llll}
\hline $\operatorname{LEV}\left(\mathbf{X}_{2}\right)$ & $-0,010$ & 0,817 & Tidak ignifikan \\
$\operatorname{SIZE~}\left(\mathbf{X}_{3}\right)$ & 0,012 & 0,002 & Signifikan \\
\hline
\end{tabular}

Persamaan regresi yang diperoleh dari pengujian tersebut adalah: Sumber: Lampiran 4

$$
Y=0,592+0,512 X_{1}-0,010 X_{2}+0,012 X_{3}+e
$$

Dari persamaan regresi linier berganda tersebut dapat dijelaskan sebagai berikut:

1. Konstanta dalam persamaan regresi tersebut adalah 0,592. Artinya, jika CSR $\left(\mathrm{X}_{1}\right)$, LEV $\left(\mathrm{X}_{2}\right)$, dan SIZE $\left(\mathrm{X}_{3}\right)$ bernilai 0 ,maka $\mathrm{ROA}(\mathrm{Y})$ sebesar 0,592 .

2. Nilai koefisien regresi variabel $\operatorname{CSR}\left(\mathrm{X}_{1}\right)$ sebesar 0,512. Artinya, jika terjadi peningkatan variabel CSR $\left(\mathrm{X}_{1}\right)$, maka nilai variabel ROA $(\mathrm{Y})$ akan mengalami peningkatan sebesar 0,512.

3. Nilai koefisien regresi variabel LEV $\left(\mathrm{X}_{2}\right)$ sebesar -0,010. Artinya, jika terjadi peningkatan variabel LEV $\left(\mathrm{X}_{2}\right)$, maka nilai variabel ROA $(\mathrm{Y})$ tidak akan mengalami perubahan.

4. Nilai koefisien regresi variabel SIZE $\left(\mathrm{X}_{3}\right)$ sebesar 0,012. Artinya, jika terjadi peningkatan variabel SIZE $\left(\mathrm{X}_{3}\right)$, maka nilai variabel ROA $(\mathrm{Y})$ akan mengalami kenaikan sebesar 0,012.

\section{Uji t}

Uji t digunakan untuk menguji signifikansi pengaruh variabel independen secara parsial terhadap variabel dependen. Hasil uji t sebagai berikut:

Tabel 3. Hasil Uji t

\begin{tabular}{ll}
\hline Variabel & Sig \\
\hline CSR $\left(\mathbf{X}_{1}\right)$ & 0,007 \\
LEV $\left(\mathbf{X}_{2}\right)$ & 0,817 \\
SIZE $\left(\mathbf{X}_{3}\right)$ & 0,002 \\
\hline
\end{tabular}

Sumber: Lampiran 5

Berdasarkan tabel tersebut dapat diketahui besar dari pengaruh masing-masing variabel independen terhadap variabel dependen sebagai berikut:

1. Pengaruh variabel CSR $\left(\mathrm{X}_{1}\right)$ terhadap variabel ROA $(\mathrm{Y})$

Berdasarkan Tabel 4.7 dapat dilihat bahwaTingkat probabilitas $(\alpha)$ adalah 0,007 . Hal ini berarti CSR berpengaruh terhadap ROA. Karena nilai probabilitas $<0,05$ maka terbukti kebenarannya $\left(\mathrm{H}_{1}\right.$ diterima).

2. Pengaruh variabel LEV $\left(\mathrm{X}_{2}\right)$ terhadap variabel ROA (Y)

Berdasarkan Tabel 4.7 dapat dilihat bahwa tingkat probabilitas $(\alpha)$ adalah 0,817 . Hal ini berarti LEVtidak berpengaruh signifikan terhadap ROA. Karena nilai probabilitas $>0,05$ maka tidak terbukti kebenarannya $\left(\mathrm{H}_{2}\right.$ ditolak).

3. Pengaruh variabel SIZE $\left(\mathrm{X}_{3}\right)$ terhadap variabel ROA (Y)

Berdasarkan Tabel 4. dapat dilihat bahwa tingkat probabilitas $(\alpha)$ adalah 0,002. Hal ini berarti SIZE berpengaruh signifikan terhadap ROA. Karena nilai probabilitas $<0,05$ maka terbukti kebenarannya ( $\mathrm{H}_{3}$ diterima).

Tabel 4. Hipotesis

\begin{tabular}{ll}
\hline Hipotesis & kesimpulan \\
\hline Pengaruh Corporate Social Responbility terhadap Return On Asset & Diterima \\
Pengaruh Laverage terhadap Return On Asset & Ditolak \\
Pengaruh Size terhadap Return On Asset & Diterima \\
\hline
\end{tabular}

\section{Pengaruh Corporate Social Responbilty Terhadap Return On Asset}

Hasil analisis regresi linier berganda pada Uji t terhadap hipotesis pertama (H1) dapat dilihat pada Tabel 4.9 bahwa CSRberpengaruhterhadap ROA dengan melihat taraf signifikansinya yaitu sebesar 0,007.Artinya semakin tinggi CSRmakaakan meningkatkanROA(H1 diterima).

Berdasarkan hasil analisis deskriptif menunjukkan bahwa nilai terendah variabel CSR adalah PT Nippon Indosari Corporindo Tbk pada tahun 2017.Nilai tertinggi variabel CSR adalah Campina Ice Cream 
Industry Tbk pada tahun 2016. Pengungkapan CSR yang lebih tinggi Campina Ice Cream Industry Tbk pada tahun 2016 berpengaruh postitif tehadap meningkatnya nilai ROA yang dihasilkan sebesar 0,5523, sedangkan nilai ROA yang dihasilkan PT Nippon Indosari Corporindo Tbk pada tahun 2017 lebih rendah sebesar 0,1265 artinya semakin tinggi pengungkapan CSR Campina Ice Cream Industry Tbk pada tahun 2016 mampu meningkatkan nilai ROACampina Ice Cream Industry Tbk pada tahun 2016.

CSR dapat dilakukan dengan berbagai cara sebagai salah satu strategi dalam meminimalisir risiko dan meningkatkan profitabilitas. Pelaksanaan CSR memberikan banyak manfaat antara lain menurunkan biaya operasional perusahaan, meningkatkan volume penjualan dan pangsa pasar, menarik calon investor melalui citra positif yang tercipta dan lain sebagainya. Reputasi perusahaan menjadi perhatian oleh calon investor yang dapat dinilai dari profitabilitas perusahaan sehingga perlu dijaga untuk mendukung keberlangsungan hidup perusahaan. Melalui CSR diharapkan mampu mencapai tujuan utama perusahaan yaitu mencari laba tanpa mengabaikan kepentingan stakeholders dan ke lestarian lingkungan sebagai bentuk tanggung jawab atas dampak yang telah ditimbulkan akibat kegiatan operasional perusahaan.

ROA digunakan untuk mengukur efektivitas perusahaan dengan keseluruhan dana yang ditanamkan dalam aktiva yang akan digunakan untuk operasi perusahaan dalam menghasilkan keuntungan (Munawir, 2010). Semakin besar ROA yang dimiliki oleh perusahaan maka semakin efisien penggunaan aktiva sehingga akanmemperbesar laba (Harmono 2014).

Hasil penelitian ini sejalan dengan penelitian Candrayanthi dan Saputra (2013), juga menjelaskan bahwa dengan adanya pengungkapan CSR, maka kinerja keuangan yang diukur dengan ROA akan meningkat. Penelitian Karjaya dan Sisdyani (2014), menunjukkan variabel CSR berpengaruh positif terhadap ROA.Jadi, dapat disimpulkan bahwa CSR berpengaruh positif terhadap ROA.

\section{Pengaruh Leverage Terhadap Return OnAsset}

Hasil analisis regresi linier berganda pada Uji t terhadap hipotesis kedua (H2) dapat dilihat pada Tabel 4.9 bahwa Leverage tidak berpengaruhterhadap ROAdengan melihat taraf signifikansinya yaitu sebesar 0,817, artinya semakin tinggi Leverage maka tidak akan memberikan perubahan terhadap ROA(H2ditolak).

Berdasarkan hasil analisis deskriptif menunjukkan bahwa nilai terendah variabel Leverage adalah PT Mayora Indah Tbk pada tahun 2016.Nilai tertinggi variabel Leverage adalah PT Tiga Pilar Sejahtera Food Tbk pada tahun 2016. Tingginya nilai Leverage tidak berpengaruh terhadap nilai ROA, hal ini dibuktikan dengan nilai ROAPT Mayora Indah Tbk sebesar 0,2752 lebih tinggi dibandingkan dengan niali ROAPT Tiga Pilar Sejahtera Food Tbk pada tahun 2016 sebesar 0,0970. Tingkat leverage yang tinggi tidak mampu menjadi tolak ukur perusahaan food and beveragedalam mengkasilkan ROA karena modal perusahaan lebih besar dibandingkan dengan modal dari aktivitas pendanaan hutang.

Leverage merupakan rasio yang menggambarkan hubungan antara hutang perusahaan terhadap total aktiva, dimana dengan rasio ini dapat dilihat seberapa jauh perusahaan dibiayai oleh hutang atau oleh pihak luar dengan kemampuan perusahaan yang digambarkan oleh besarnya total aktiva suatu perusahaan (Febrina dan Suaryana, 2011). Selain itu, Leverage juga menggambarkan struktur modal yang dimiliki suatu perusahaan, sehingga tingkat resiko tak tertagihnya suatu hutang dapat dilihat.

Struktur modal merupakan bauran antara hutang dengan modal atau yang biasa disebut debt to equity ratio (DER). Penggunaan hutang dalam suatu perusahaan akan menaikkan nilai saham, karena adanya kenaikan pajak yang merupakan pos deduksi terhadap biaya hutang, namun pada titik tertentu penggunaan hutang dapat menurunkan nilai saham kerana adanya pengaruh biaya kepailitan dan biaya bunga yang ditimbulkan dari adanya penggunaan hutang. Dengan adanya pajak maka perusahaan atau harga saham dipengaruhi oleh struktur modal, semakin tinggi proporsi hutang yang digunakan maka akan semakin tinggi harga saham penggunaan hutang. Kebijakanpendanaan yang tercermin dalam debt to equity ratio(DER) sangat mempengaruhi pencapaian laba yang diperoleh perusahaan.Rasio ini berfungsi untuk mengetahui setiap rupiah modal sendiri yang dijadikan untuk jaminan hutang. Semakin tinggi DER akanmempengaruhi besarnya ROA yang dicapai perusahaan

Hasil penelitian ini sejalan dengan penelitian sebelumnya yang dilakukan oleh Etik Murniati (2017) yang menyatakan bahwa LEV tidak berpengaruh terhadap ROA. Jadi dapat disimpulkan bahwa LEV tidak berpengaruh terhadap ROA.

\section{Pengaruh SIZETerhadap Return On Asset}

Hasil analisis regresi linier berganda pada Uji t terhadap hipotesis ketiga (H3) dapat dilihat pada Tabel 4.9 bahwa SIZE berpengaruhterhadap ROAdengan melihat taraf signifikansinya yaitu sebesar 0,002.Artinya semakin tinggi SIZE makaakan meningkatkanROA (H3diterima).

Berdasarkan hasil analisis deskriptif menunjukkan bahwa nilai terendah variabel SIZE adalah PT Buyung Poetra Sembada Tbk pada tahun 2017.Nilai tertinggi variabel SIZE adalah PT Indofood Sukses 
Makmur Tbktahun 2017. Ukuran perusahaan PT Indofood Sukses Makmur Tbktahun 2017 yang besar terbukti dapat menghasilkan nilai ROA sebesar 0,1466, artinya nilai ROA PT Indofood Sukses Makmur Tbk tahun 2017 lebih besar bila dibandingkan dengan PT Buyung Poetra Sembada Tbk yang hanya mampu menghasilkan nilai ROA sebesar 0,0321. Semakin besar ukuran perusahaan yang diukur melalui total aset yang dimiliki memberikan dampak positif terhadap nilai ROA yang dihasilkan PT Indofood Sukses Makmur Tbk.

Ukuran perusahaan menggambarkan besar atau kecilnya suatu perusahaan yang diukur dengan mengetahui total aktiva atau total aset yang dimiliki perusahaan tersebut. Skala perusahaan merupakan ukuran yang dipakai untuk mencerminkan besar kecilnya perusahaan yang didasarkan pada total aset perusahaan (Suwito dan Herawaty, 2005). Semakin besar perusahaan atau semakin besar skala perusahaan maka semakin banyak dana yang digunakan untuk menjalankan operasi perusahaan sehingga tingkat efisiensi perusahaan pun meningkat, salah satu sumbernya adalah hutang. Brigham (2009), menyatakan bahwa perusahaan yang memiliki tingkat pertumbuhan yang tinggi cenderung membutuhkan dana dari sumber eksternal yang besar. Peningkatan hutang bisa meningkatkan nilai perusahaan.

Ukuran atau Size dari sebuah perusahaan dapat juga dilihat dari beberapa hal, seperti struktur organisasi, jumlah karyawan, aset perusahaan, dan jumlah saham yang beredar. Semakin besar skala perusahaan maka profitabilitas juga akan meningkat, karena dengan adanya sumber daya yang besar, maka perusahaan dapat melakukan investasi baik untuk aktiva lancar maupun aktiva tetap dan juga memenuhi permintaan produk.Namun Ukuran perusahaan atau skala usaha yang besar belum tentu bisa menjamin profitabilitas perusahaan baik, karena perusahaan besar mungkin belum berani melakukan investasi baru terkait dengan ekspansi, sebelum hutangnya terlunasi. Siregar dan Utama (2005), menemukan bahwa ukuran perusahaan berpengaruh terhadap profitabilitas (ROA). Jadi dapat disimpulkan bahwa SIZE berpengaruh terhadap ROA

\section{Simpulan dan saran}

Penelitian ini bertujuan untuk menguji pengaruh CSR, LEV dan SIZE terhadap ROA. Berdasarkan sampel yang digunakan dalam penelitian ini yaitu 14 Perusahaan food and beverage tahun 2016-2018 dan ditentukan dengan menggunakan metode purposive sampling. Berdasarkan pembahasan pada bab IV dapat diambil kesimpulan yakni hasil pengujian regresi berganda atas pengaruh CSR terhadap ROA menunjukkan pengaruh positif signifikan. Ini membuktikan bahwa semakin besar CSR akan meningkatkan ROA. Hasil pengujian regresi berganda atas pengaruh LEV terhadap ROA menunjukkan tidak berpengaruh signifikan. Ini membuktikan bahwa LEV yang tinggi maka ROA tidak akan mengalami perubahan. Hasil pengujian regresi berganda atas pengaruh SIZE terhadap ROA menunjukkan pengaruh yang positif dan signifikan. Ini membuktikan bahwa SIZE yang tinggi akanmeningkatkan ROA

Bagi peneliti selanjutnya, sebaiknya memperluas kriteria sampel pada perusahaan pertambangan dan perusahaan jasa yang terdaftar di Bursa Efek Indonesia (BEI). Bagi peneliti selanjutnya diharapkan melakukan penambahan sampel tahun penelititan yang lebih banyak agar dapat menggambarkan kondisi yang lebih konkrit misalnya 10 tahun

\section{Daftar Rujukan}

Ajilaksana, I Dewa Ketut Yudyana. 2011. “Pengaruh Corporate Social Responsibility terhadap kinerja keuangan perusahaan”. Skripsi Universitas Diponegoro: Semarang

Anggraini, Fr. R. R. 2006. Pengungkapan Informasi Sosial dan Faktor-faktor yang Mempengaruhi Pengungkapan Informasi Sosial dalam Laporan Keuangan Tahunan.Simposium Nasional Akuntansi IX. Padang. 23-26 Agustus.

Arisadi, Yunita Castelia. Djumahir. Atim Djazuli. 2013. "Pengaruh Ukuran Perusahaan, Umur Perusahaan, Current Ratio, Debt to Equity Ratio, dan Fixed Asset to Total Asset RatioTerhadap Kinerja Keuangan pada Perusahaan Manufaktur di Bursa Efek Indonesia". Jurnal Aplikasi Manajemen, Vol. 11, No. 4; 567-574.

Attig, N., S. El Ghoul, O. Guedhami dan S. Rizeanu (2011). "The governance role of multiple large shareholders: evidence from the valuation of cash holdings". Journal of Management and Governance: 1-33. 
Ayu Pratiwi, 2018. Pengaruh Corporate Social Responsibility (CSR), Leverage Dan Size Terhadap Profitabilitas Pada Perusahaan Properti, Real Estate Dan Kontruksi Bangunan Yang Terdaftar Di Bursa Efek Indonesia Tahun 2011-2015. Universitas Diponegoro Semarang.

Brigham, Eugene and Joel F. Houston. 2009. Dasar-Dasar Manajemen Keuangan. Edisi Sepuluh. Alih Bahasa Ali Akbar Yulianto. Jakarta: Salemba Empat.

Candrayanthi, Alit A.A dan Saputra, Dharma I D.G. 2013. "Pengaruh Pengungkapan Corporate Social Responsibility Terhadap Kinerja Perusahaan (Studi Empiris Pada Perusahaan Pertambangan di Bursa Efek Indoneia". E-jurnal Akuntansi Universitas Udayana 4.1: 141-158.

Dahlia, D. dan Siregar.2008.“Pengaruh Corporate Social Responsibility Terhadap Nilai Perusahaan Dengan Profitabilitas Sebagai Variabel Moderating (Studi Empiris pada Perusahaan Manufaktur yang terdaftar di Bursa Efek Indonesia").Skripsi. Program S1 Fakultas Ekonomi Universitas Diponegoro. Semarang.

Etik Murniati (2017). Pengaruh Corporate Social Responsibility (CSR), Ukuran Perusahaan (Size ) Dan Leverage Terhadap Profitabilitas Di Perusahaan Lq-45 Periode 2014-2015. Universitas Brwaijaya Malang

Etik Murniati, 2017. Pengaruh Corporate Social Responsibility (CSR), Ukuran Perusahaan (Size ) Dan Leverage Terhadap Profitabilitas Di Perusahaan Lq-45 Periode 2014-2015. Universitas Hassanudin, Makassar

Gartchie Gatsi, 2013. Degree of Financial and Operating Leverage and Profitability of Insurance Firms in Ghana

Ghozali, Imam. 2013. Aplikasi Analisis Multiariate dengan Program IBM SPSS. 21. Edisi 7. Semarang: Badan Penerbit Universitas Diponegoro.

Gujarati, Damodar, \& Porter, Dawn C. 2010.Dasar-Dasar Ekonometrika. Jakarta. Salemba Empat.

Hackston, David and Markus J. Milne. 1996. Some Determinants of Social and Environmental Disclosure in New Zealand Companies. Accounting

Hafezali Hussain, 2019. Sustainability of Leverage Levels in Response to Shocks in Equity Prices: Islamic Finance as a Socially Responsible Investment

Ida Purba (2015). Pengaruh Ukuran Perusahaan Dan Leverage Terhadap Profitabilitas Dan Pengungkapan Corporate Social Responsibility.Universitas Udayana Bali

Jogiyanto.2000. Teori Portofolio dan Analisis Investasi Cetakan Ketiga.Edisi 7.BPFEYogyakarta.Yogyakarta

Kasmir. 2016. Analisis Laporan Keuangan. Jakarta: Raja Grafindo Persada

Keown. 2004. Manajemen Keuangan : Prinsip-Prinsip dan Aplikasi. Edisi 9, Indeks. Jakarta.

Lais, 2015. Pengaruh Ukuran Perusahaaan, Profitabilitas, Leverage, dan Tipe Kepemilikan terhadap Voluntary Disclosure Laporan Keuangan Tahunan. Procedding PESAT, vol. 2, 21- 22 Agustus 2007. Auditorium Kampus Gunadarma

Martiani, 2009.Dasar-Dasar Manajemen Keuangan. Edisi Keempat. Yogyakarta: UUP AMP YKPN

Nawangsari, 2016.Pengaruh Kepemilikan Institusional, Kepemilikan Manajemen dan Kepemilikan Asing terhadap Pengungkapan Corporate Social Responsibility (Studi pada Perusahaan Manufaktur yang Terdaftar di BEI tahun 2012-2014). Universitas Jember 
Robby Heryanto, 2017.Pengaruh Corporate Social Responsibility Terhadap Profitabilitas Perusahaan (Studi Empiris Pada Perusahaan Manufaktur Yang Terdaftar Di Bursa Efek Indonesia Periode 20142015).Universitas Diponegoro Semarang.

Sayekti, Yosefa dan Ludovicus Wondabio, 2007.Pengaruh CSR Disclosure terhadap Earning Response Coefficient.Simponsium Nasional Akuntansi X. 26-28 Juli 2007.Makassar.

Untung, 2008.Corporate Social Responsibility. Jakarta: Sinar Grafika.

Wela Putra (2015). Pengaruh Leverage, Pertumbuhan Penjualan Dan Ukuran Perusahaan Terhadap Profitabilitas. STIE Perbanas Surabaya 